\title{
Performance of Toria using INM under Late Sown Rainfed Condition in Rice Fallow of Udalguri District of Assam, India
}

\author{
Ipsita Ojah $^{1 *}$, Debasish Borah ${ }^{1}$, Himadri Rabha ${ }^{2}$ and Pallabi Deka ${ }^{3}$ \\ ${ }^{1}$ Soil Science, ${ }^{2}$ Plant Protection, ${ }^{3}$ Agricultural Economics and farm management, Krishi \\ Vigyan Kendra, Assam Agricultural University, BTAD, Lalpool, District: Udalguri- 784514; \\ Assam, India \\ *Corresponding author
}

\section{A B S T R A C T}

\begin{tabular}{|l|}
\hline Ke y w o r d s \\
$\begin{array}{l}\text { Toria, Late-sown, } \\
\text { demonstration, } \\
\text { Yield and } \\
\text { economics }\end{array}$ \\
\hline Article Info \\
\hline $\begin{array}{l}\text { Accepted: } \\
\text { 22 June } 2020 \\
\text { Available Online: } \\
\text { 10 July 2020 }\end{array}$ \\
\hline
\end{tabular}

Toria is an important rabi oilseed crop in Udalguri district of Assam. In Kharif season, farmers of Udalguri district mainly grow long duration rice as mono crop in rainfed situation. Till rice is harvested, it already becomes late for sowing normal sown varieties of Toria. Udalguri district has a sizeable area under toria cultivation, but the productivity is very low. The reasons of low productivity can be related to the poor knowledge about the new technologies (cultivation and soil management practices) of most of the farmers. Due to such circumstances, a demonstration has been conducted using late sown Toria variety (TS-67) using Integrated Nutrient Management (INM) with the objective to convert the area into a double cropping system as well increase farmers income, to decrease the deficit of oil in the district. The study was carried out through participatory cluster front line demonstration (CFLD) during rabi season of 2017-18, 2018-19 and 2019-20 at four different villages of Udalguri district under north bank plain zone of Assam on farmers field with an objective to evaluate the performances of late-sown Toria variety TS-67 as compared to the farmers practice.

\section{Introduction}

Toria is the main oilseed crop grown in Assam on commercial basis occupying an area of 2.85 lakh hectares with annual production of 1.99 lakh tonnes of seed and productivity $698 \mathrm{~kg} \mathrm{ha}^{-1}$ (Govt. of Assam 2016); which is very poor as compared to national average productivity $(1151 \mathrm{~kg} / \mathrm{ha})$. Rainfed cultivation, poor nutrient management and delay in sowing are some of the reason for low productivity of the crop in the state. Toria is usually sown from midOctober to mid-November in Assam. However, in medium low land, clay loam to sandy loam soil the crop is sown late which sometimes goes up to December after harvesting of Sali rice (November) in ricetoria cropping system. Due to delay in sowing the crop may get Aphid infestation, which may result in low yield of the crop; thus, reducing farmers' income. Delay in sowing adversely influence the crop performance, mainly due to depletion of soil moisture 
affecting flowering and early siliqua formation causing poor seed filling. As a result, the yield suffers mainly due to moisture stress under poor nutrient supply. Singh et al., (1991) also reported that toriacrop was most sensitive to moisture stress from vegetative to early flowering stage when it was grown under a wide variety of limited irrigation conditions. So, a suitable irrigation management practice with proper nutrient management is necessary to boost up the productivity of the crop since the crop is highly responsive to fertilizers, particularly to nitrogen, phosphorus, and potassium (Allen and Morgan, 1972). But, the harmers of Udalguri district mainy cultivate toria in rainfed situation owing to the fact that many of them are devoid of irrigation facilities. So, the present study was conducted in farmers' field of Udalguri district in rainfed situation with a view to study the performance of a late sown toria variety viz. TS-67 with Integrated Nutrient Management (INM) practices.

\section{Materials and Methods}

The study was carried out during rabi season on 2017-18, 2018-19 and 2019-20 (3 consecutive years) by Krishi Vigyan Kendra, Udalguri, Assam Agricultural University. The demonstrations were being conducted in farmers' field of four different villages of Udalguri district. Udalguri falls under North Bank Plain agro climatic zone of Assam. The soil type of the district is sandy clay loam soil.

A total of 75numbers of farmers were selected randomly for conducting the study within 4 villages of the district viz. Daifang, Ganakpara, Kacharitol and Chonbari. The study was conducted in an area of 10 ha each year for three years consecutively.
Before land preparation was done, farmers were trained to follow the integrated nutrient management (INM) practice under the Package of practice, 2015, by Assam Agricultural University for the demonstration plot. The INM practice (demonstration) and farmers' practice (check) are described in table number 1 :

The farmers followed the full package of practice like land preparation, seed treatment, proper seed rate, manure and fertilizer application, weed management and plant protection measures for the demonstration plot. For the check plot (control), the traditional practices of farmers of Udalguri district was followed using existing varieties and cultivation practices.

The data were collected from both demonstration plots and control plots and finally, the extension gap, technology gap, technology index with the cost benefit ratio (Samui et al., 2000) were calculated as follows:

$$
\begin{aligned}
& \text { Technology gap }=\text { Potential yield }- \text { Demonstration yield } \\
& \text { Extension gap }=\text { Demonstration yield }- \text { Farmers yield } \\
& \text { Technology index = Potential yield }- \text { Demonstration yield } \\
& \text { Potential yield }
\end{aligned}
$$

\section{Results and Discussion}

The result of the study for three years in four different villages of Udalguri district indicated that, the cultivation practices comprised under the demonstration plot produced on an average $22 \%$ more yield of toria compared to check plot. The findings are in conformity with Dutta, 2014; though the increase was up to $38 \%$. 
Table.1 Details of INM (demonstration) and farmers' practice for cultivation of Toria followed for the study

\begin{tabular}{|c|c|c|}
\hline Particulars & Demonstration (INM) & Check (Control) \\
\hline Farming situation & Rainfed medium land & Rainfed medium land \\
\hline Time of sowing & Mid November & Mid November \\
\hline Method of sowing & Line-sowing & Broadcasting \\
\hline Seedrate & $10 \mathrm{~kg} / \mathrm{ha}$ & $12 \mathrm{~kg} / \mathrm{ha}$ \\
\hline Seed treatment & Metalaxyl 35WS @6 g / kg of seeds & Nil \\
\hline Manures/ Fertilizers & $\begin{array}{l}\text { Fertilizers: } 75 \% \text { of recommended Dose of } \\
\text { Fertilizer i.e. } 30 \mathrm{Kg} \mathrm{N}, 26.25 \mathrm{Kg} \mathrm{P} 2 \mathrm{O} 5 \text {, } \\
11.25 \mathrm{~K} 2 \mathrm{O} / \mathrm{ha} \text { (Farmers contibution) + } \\
\text { Vermicompost / Compost @ } 1.5 \mathrm{q} / \mathrm{ha}+ \\
\text { FYM @ } 2.5 \mathrm{t} / \mathrm{ha}+\mathrm{S} @ 20 \mathrm{~kg} / \mathrm{ha}\end{array}$ & $\begin{array}{l}\text { Non-judicious and imbalanced application of } \\
\text { fertilizers mainly DAP with no application of } \\
\text { sulphur were under consideration. }\end{array}$ \\
\hline \multirow[t]{2}{*}{ Plant protection } & $\begin{array}{l}\text { Dimethoate } 30 \text { EC @ } 0.51 \text { /ha against } \\
\text { Aphid }\end{array}$ & Nil \\
\hline & Mancozeb@0.2\% for Alternaria blight & Mancozeb @ $0.2 \%$ for Alternaria blight \\
\hline
\end{tabular}

Table.2 Mean value of Initial Soil Fertility Status of the five villages of Udalguri district

\begin{tabular}{|c|c|c|c|c|}
\hline pH & $\mathrm{OC}(\%)$ & Av. N (kg/ha) & $\begin{array}{ll}\text { Av. } & \mathrm{P}_{2} \mathrm{O}_{5} \\
(\mathrm{~kg} / \mathrm{ha}) & \end{array}$ & $\begin{array}{ll}\text { Av. } & \mathrm{K}_{2} \mathrm{O} \\
\text { (kg/ha) } & \end{array}$ \\
\hline 5.2 & 0.78 & 233.33 & 20.92 & 132.25 \\
\hline
\end{tabular}

*The values in table are the mean of four villages shown year wise

Table.3 Mean Residual Soil Fertility Status of the four villages of Udalguri district

\begin{tabular}{|c|c|c|c|c|c|c|}
\hline Year & Trial & pH & OC $(\%)$ & Av.N (kgha $\left.{ }^{-1}\right)$ & Av. $P_{2} O_{5}\left(k g h a^{-1}\right)$ & Av. $K_{2} \mathrm{O}\left(\mathrm{kgha}^{-1}\right)$ \\
\hline \multirow[t]{2}{*}{ 2017-18 } & Demonstration & 5.2 & 0.77 & 234.74 & 21.56 & 133.59 \\
\hline & Local Check & 5.1 & 0.75 & 229.56 & 18.45 & 131.74 \\
\hline \multirow[t]{2}{*}{ 2018-19 } & Demonstration & 5.3 & 0.79 & 236.13 & 21.07 & 134.45 \\
\hline & Local Check & 5.1 & 0.76 & 230.14 & 18.96 & 130.95 \\
\hline \multirow[t]{2}{*}{ 2019-20 } & Demonstration & 5.3 & 0.81 & 237.89 & 22.18 & 133.89 \\
\hline & Local Check & 5.2 & 0.76 & 230.98 & 20.84 & 131.78 \\
\hline
\end{tabular}

*The values in table are the mean of four villages shown year wise

Table.4 Growth and Yield Attributes of three years

\begin{tabular}{|c|c|c|c|c|c|c|c|}
\hline Year & Trial & $\begin{array}{l}\text { No. of } \\
\text { siliqua } \\
\text { plant-1 }\end{array}$ & $\begin{array}{l}\text { No. of seeds } \\
\text { siliqua-1 }\end{array}$ & $\begin{array}{c}\text { Potential } \\
\text { yield of seed } \\
\left(\mathbf{q} \mathbf{h a}^{-1}\right)\end{array}$ & $\begin{array}{l}\text { Seed Yield } \\
\left(\mathrm{qha}^{-1}\right)\end{array}$ & $\begin{array}{c}\% \\
\text { Increase } \\
\text { in Yield }\end{array}$ & $\begin{array}{l}\text { Stover Yield } \\
\quad\left(\mathrm{qha}^{-1}\right)\end{array}$ \\
\hline \multirow[t]{2}{*}{ 2017-18 } & Demonstration & 63 & 23 & \multirow[t]{2}{*}{10} & 7.5 & \multirow[t]{2}{*}{27} & 21 \\
\hline & Local Check & 54 & 15 & & 5.9 & & 18 \\
\hline \multirow[t]{2}{*}{ 2018-19 } & Demonstration & 68 & 25 & \multirow[t]{2}{*}{10} & 8.1 & \multirow[t]{2}{*}{19} & 22 \\
\hline & Local Check & 58 & 19 & & 6.8 & & 20 \\
\hline \multirow[t]{2}{*}{ 2019-20 } & Demonstration & 65 & 25 & \multirow[t]{2}{*}{10} & 7.8 & \multirow[t]{2}{*}{20} & 21 \\
\hline & Local Check & 56 & 17 & & 6.5 & & 19 \\
\hline \multicolumn{6}{|c|}{ Average increase in yield over three years (\%) } & \multicolumn{2}{|l|}{22} \\
\hline
\end{tabular}

*The values in table are the mean of four villages shown year wise 
Table.5 Economics of Cultivation of Toria for 3 years in farmers field

\begin{tabular}{|l|l|c|c|c|c|}
\hline Year & Trial & $\begin{array}{c}\text { Gross Cost } \\
\text { (Rs.) }\end{array}$ & $\begin{array}{c}\text { Gross Return } \\
\text { (Rs.) }\end{array}$ & $\begin{array}{c}\text { Net Return } \\
\text { (Rs.) }\end{array}$ & B: C Ratio(Rs.) \\
\hline \multirow{2}{*}{$\mathbf{2 0 1 7 - 1 8}$} & Demonstration & 19620.00 & 27750.00 & 8130.00 & 1.4 \\
\cline { 2 - 6 } & Local Check & 17400.00 & 21830.00 & 4430.00 & 1.25 \\
\hline \multirow{2}{*2018-19}{} & Demonstration & 20410.00 & 29970.00 & 9560.00 & 1.46 \\
\cline { 2 - 6 } & Local Check & 18600.00 & 25160.00 & 6560.00 & 1.35 \\
\hline \multirow{2}{*2019-20}{} & Demonstration & 20410.00 & 28860.00 & 8450.00 & 1.41 \\
\cline { 2 - 6 } & Local Check & 18600.00 & 24050.00 & 5450.00 & 1.29 \\
\hline
\end{tabular}

*The values in table are the mean of four villages shown year wise

Fig.1 Yield Gap Analysis (Coloured representation)

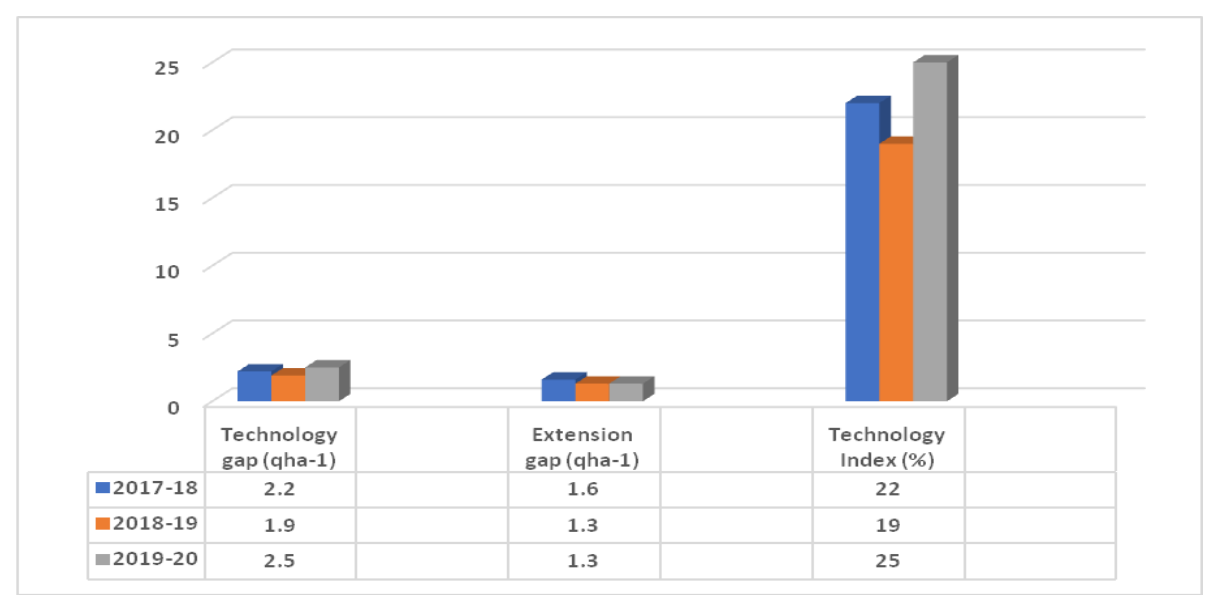

\section{Initial and Final Soil Fertility Status}

The mean value of initial soil fertility status of the four villages, that were collected before conducting the study, are given in table number 2. After conducting the study, there is change in the residual soil fertility status beginning from the first year (2017-18) itself. The year wise mean value of residual soil fertility status of the four villages are given in table number 3 . It was observed that there is increase in organic carbon (OC) in the demonstration plot during the study, the highest being in the year 2029-20 (0.76 \%); this increase was also seen as compared to the check plot. Similar increase was also observed in case of Av. $\mathrm{N}$ and Av. $\mathrm{P}_{2} \mathrm{O}_{5}$ (22.18 $\mathrm{kg} \mathrm{ha}^{-1}$ ), although highest Av. $\mathrm{K}_{2} \mathrm{O}$ $\left(134.45 \mathrm{~kg} \mathrm{ha}^{-1}\right)$ was observed in the year 2018-19.

\section{Growth and Yield Attributes}

Effect of demonstration and check study on Growth and Yield Attributes of Toria viz. number of siliqua plant ${ }^{-1}$, number of seeds siliqua $^{-1}$, seed and stover yield in three years are presented in table number 4.The Growth parameters were higher in demonstration plot in all the three years as compared to local check. TS-67 variety of toria considered in the demonstration plot produced the maximum seed (8.1 q/ha) and stover yield (22 $\mathrm{q} / \mathrm{ha}$ ) in the second year of study (2018-19).

\section{Yield Gap Analysis}

The technology gap, extension gap and technology index calculated for the three years study, are depicted in graphical form in Figure number 1. It was observed that the technology 
gap was lowest in the year 2018-19 (1.9 q/ha). Similar result was observed in case of technology index (0.19). In case of extension gap, the second (2018-19) and third (2019-20) year showed similar data of $1.3 \mathrm{q} / \mathrm{ha}$.

\section{Economics of Cultivation}

An analysis on economics (Table 5) revealed that Toria in demonstration (TS-67) recorded the higher gross return Rs. $29970.00 \mathrm{ha}^{-1} \&$ net profit of Rs. $9560.00 \mathrm{ha}^{-1}$ in the second year. The Gross return and net return from toria cultivation were higher in all the three years as compared to check. The B: $\mathrm{C}$ ratio in the demonstration plot in all the three years of study were almost similar, but are more as compared to the check plot.

\section{Initial and Final Soil Fertility Status}

During the study, it was observed that there is increase in organic carbon (OC) in the demonstration plot compared to check plot in all the three years. The highest OC was found in the demonstration plot of the second year viz. 2029-20 (0.76 \%). It was due to proper management of manures and fertilizers compared to the check plots. Similar results were also observed in case of Av. $\mathrm{N}$ and Av. $\mathrm{P}_{2} \mathrm{O}_{5}\left(22.18 \mathrm{~kg} \mathrm{ha}^{-1}\right)$, although highest Av. $\mathrm{K}_{2} \mathrm{O}\left(134.45 \mathrm{~kg} \mathrm{ha}^{-1}\right)$ was observed in the year 2018-19. This is due to proper fertility management (integrated nutrient management) in the demonstration plot as compared to the check plot. INM improves the nutrient uptake by mustard and hence enhances the use efficiency of various nutrients from the soil (Shekhawat et al., 2012).

\section{Growth Parameters and Yield Attributing Characters}

The Growth parameters and Yield attributing characters (Table 4) viz number of siliqua plant $^{-1}$, number of seeds siliqua ${ }^{-1}$, seed and stover yield were higher in demonstration plot in all the three years as compared to local check due to their genetic variability and environmental adaptability of varieties (TS-67 in demostration and Local behor in check plot). Similar results were also obtained in mustard, which is described asowing to increased dry matter production and higher translocation of food material for formation of seed in advanced sowing by Kumari et al., 2012). TS-67 variety of toria considered in the demonstration plot, produced the maximum seed $(8.1 \mathrm{q} / \mathrm{ha})$ and stover yield (22 $\mathrm{q} / \mathrm{ha}$ ) in the second year of study (2018-19). The said variety also produced the maximum seed yield of $8.1 \mathrm{q} \mathrm{ha}^{-1}$ in the second year (2018-19) which is $19 \%$ higher than that of existing local variety i.e. Local Behor $(6.8 \mathrm{q}$ $\mathrm{ha}^{-1}$ ) which is due to higher number of siliquae per plant (68 nos.) and seeds per siliqua(25 nos.) (Table 4). The trend of stover yields of toria in the three years was almost similar with seed yields.

Maximum Stover yield (22 q ha ${ }^{-1}$ ) was obtained from TS-67 in the second year (2019-20). The overall growth parameters of demonstration plot in the third year (2019-20) area bit less compared to the demonstration in the second year (2018-19) although performance is better than check plot. This may be attributed to dissimilarity in weather conditions mainly due to non-availability of irrigation water.

\section{Yield Gap Analysis}

During the study, the trend of technology gap (ranging from $1.9-2.5 \mathrm{q} \mathrm{ha}^{-1}$ ) reflects the farmers' cooperation in carrying out the demonstration with encouraging results in the third year i.e. 2019-20 (2.5 q ha $\left.{ }^{-1}\right)$. The extension gap in three years study (ranging from $1.6 \mathrm{q} \mathrm{ha}{ }^{-1}-1.3 \mathrm{q} \mathrm{ha}^{-1}$ ) showed a decreasing trend; and also, a narrow range 
indicating the farmers have adopted the improved cultivation practices of the demonstration plot.

It was observed that the technology gap was lowest in the year 2018-19 (1.9 q/ha). The lower the value of technology index, the more feasible is the technology. The values of technology index varied from (19\% to $25 \%)$ (Fig 1) during the study period in certain region may be attributed to dissimilarity in weather conditions mainly due to nonavailability of irrigation water (Dutta, 2014). In case of extension gap, the second (201819) and third (2019-20) year showed similar data of $1.3 \mathrm{q} / \mathrm{ha}$.

\section{Economics of Cultivation}

An analysis on economics (Table 5) revealed that Toria in demonstration (TS-67) recorded the higher gross return Rs. $29970.00 \mathrm{ha}^{-1} \&$ net profit of Rs. $9560.00 \mathrm{ha}^{-1}$ in the second year. This result is similar with the findings of Dutta, 2014. The Gross return and net return from toria cultivation were higher in all the three years as compared to check. The B: C ratio in the demonstration plot in all the three years of study were almost similar, but are more as compared to the check plot.

In conclusion thus, the cultivation of Toria TS-67 with integrated nutrient management (as conducted under the demonstration plot) was found to be more productive and can replace the local check i.e. farmers' practice since it fits to the existing farming situation for higher productivity \& income. The practice under demonstration plot is not only the scientific basis for balanced fertilization but it also enables farmer to choose the proper fertilizer management practices. It can also reduce the technology gap to a considerable extent; which would be beneficial for the farming community.

\section{Acknowledgement}

The authors are thankful to the Director, ATARI, Zone VI, Guwahati (ICAR) for providing financial assistance towards organizing the cluster front line demonstration under NMOOP (Rabi Oilseeds).

\section{References}

Allen, E.J. and Morgan, D.G., 1972. A quantitative analysis of the effect of nitrogen on the growth, development and yield of oilseed rape. J. Agri. Sci., (Camb.). 78, 315-324.

Dutta, R., 2014. Yield gap analysis of Rapeseed - Mustard in North Bank Plain Zone of Assam. Indian Res. J. Ext. Edu., 14, 3-8.

Kumari, A; Singh, R.P;Yeshpal., 2012. Productivity, nutrient uptake and economics of mustard hybrid (Brassica juncea) under different planting time and row spacing, Indian Journal of Agronomy, 57(1), 61-67.

Rawat, R.F; Hamid, A; Hadole, S.S;Jeughale, G.S., 2000 Effect of irrigation and sulphur on concentration, uptake and availability of sulphur, nitrogen and phophorus in mustard (Brassica juncea). Journal of Soils and Crops, 10, 145-148.

Samui, S. K. Maitra, S; Roy, D.K; Mandal, A.K. and Saha, D., 2020. Evaluation of front-line demonstration on groundnut. J. Indian Soc. Coastal Agri. Res., 18 (2): 180-183.

Shekhawat, K; Rathore, S.S; Premi, O.P; Kandpal, B. K. and Chauhan, J.S., 2012. Advances in Agronomic Management of Indian Mustard (Brassica juncea (L.) Czernj. Cosson): An Overview. International Journal of Agronomy, 12: doi:10.1155/2012/408284

Singh, P.K; Mishra, A.K; Imtiyaz, M., 1991. Moisture stress and water use efficiency of mustard. Agril. Water Mngt., 20(3), 245-253. 


\section{How to cite this article:}

Ipsita Ojah, Debasish Borah, Himadri Rabha and Pallabi Deka. 2020. Performance of Toria using INM under Late Sown Rainfed Condition in Rice Fallow of Udalguri District of Assam, India. Int.J.Curr.Microbiol.App.Sci. 9(07): 2799-2805.

doi: https://doi.org/10.20546/ijcmas.2020.907.330 